\title{
Aesopic Fables in the European and the Modern Greek Enlightenment
}

\author{
George C. Katsadoros \\ George C. Katsadoros, Department of Primary Education, University of the Aegean \\ Demokratias 1 Avenue, Rhodes 85100, Greece \\ E-mail: katsadoros@rhodes.aegean.gr
}

Received: May 14, $2011 \quad$ Accepted: June 15, $2011 \quad$ Published: December 1, 2011
doi:10.5539/res.v3n2p110

\begin{abstract}
Aesopic fables constitute an important case in popular literature. This genre went through various stages of development, as its practical and educational value was recognized from the beginning; its plasticity, pedagogical dimension and mainly its ability to convey messages through an indirect and pleasant way prompted many to take interest in it, reading, adapting or even creating new fables. Initially, these fables were developed for use in linguistic education and later they assumed a pedagogical and simultaneously literary character, while, in many cases, they became a means of indirect expression and protest. Even though generation and adaptation of fables was recorded in almost every era and country, it was greatly increased with the movement of the European (1687-1789) and of the Modern Greek Enlightenment (1750-1821). The messages of these fables appeared to be aiming at the liberation of man from ignorance and superstition. This paper aims to demonstrate this 'Aesopic production' specifically in the time of the Enlightenment (or shortly thereafter, influenced by its spirit), presenting related works in Europe and Greece.
\end{abstract}

Keywords: Aesop, Fables, Enlightenment

Animal fables, this ancient literary genre that was connected early on with the legendary name of Aesop (Note 1), even if not initially addressed to children, are very popular, possessing a particular pedagogic value largely owing to their plasticity and adaptability. The indirect means of expression, teaching, and even protest that characterizes this genre (Note 1) offered capable adapters the possibility of approaching numerous vital questions while simultaneously maintaining a 'safe distance'. The many variants and variations of fables throughout the world, as well as their resemblance to folktales, indicate that Aesop's fables stem from popular literature (Author, 2005:72). Meanwhile, many notable figures of ancient, medieval and modern scholarship have concerned themselves with this genre, such as Leonardo da Vinci, Martin Luther, Leo Tolstoy and others (Van Dijk, 1997:Xiii).

The first collection of fables is attributed to Demetrius Phalereus (Hellenistic period, around 300 B.C.E.). The publication of five books containing fables (Fabulae Aesopicae, 1st century B.C.E.) in Latin verse by the Thracian freedman Phaedrus, which inaugurated the artistic writing of fables (Roemer, 1998:196), is also considered of great importance for the development of the fable. The above collections, along with Aesop Romance (note 1), form the corpus of Aesopic fables.

From the Greco-Roman era onwards, animal fables were considered eminently suitable for teaching and constituted very popular reading material. Until the 12 th century C.E., collections of fables were developed mainly as utilitarian handbooks for orators. At the end of that century they began to be appreciated as a distinct art form, and assumed two new functions: that of socio-political satire and that of art. Both forms reached their apogee in France, particularly with La Fontaine's fables.

The fictitious appearance of fables' presumed father, Aesop, served as a voice urging the release of the human spirit from social restrictions and aesthetic biases: this voice, already apparent in antiquity, aimed to demolish the prevailing model of the obligatory coexistence of inner and outer beauty. This revolution was not limited to the aesthetic field; it also had social implications, conveying the optimistic message that everyone, regardless of natural or social privileges, had the opportunity to excel in life. Aesop, disfigured and repulsive and of the lowest social status (a slave), managed through his spirit alone not only to gain his freedom but also to surpass the powerful and wise men of his time. Even if there were many 'Aesops', particularly of eastern origin, the Aesop of 
Greek tradition became a voice of resistance against the established order, which in the end led him to an unjust death.

The Enlightenment brought animal fables once more to the fore. Apart from their inexhaustible possibilities for literary and pedagogical employment, this genre vindicated the return of man to 'wise' and 'virtuous' nature. Furthermore, the Enlightenment proposed the pre-eminence of the criterion of human judgement and a critical approach to each institution and theory, wherein "even philosophers have to accept common sense" (Eco, 32006:107-108). Animal fables were ideal for such exploitation, as their structure is based precisely on contradistinctions between rich and poor, just and unjust, powerful and powerless. The animals presented in fables function as representations of one or another social model, and consequently reveal social conflicts. Moreover, the message of these fables is often based on an inversion of natural order (Röhrich, 2008:150).

Apart from the tendency towards didacticism, the popularity of animal fables in the 17th and 18th centuries was also enhanced by that period's interest in literature. Certainly writers who composed or adapted Aesopic fables utilized previous similar fables, which they greatly respected, whether or not they were drawn to the same conclusions-epimythia; they transformed various fables into a flexible means of conveying facts, opinions, and critique. While fables were considered to challenge the established social hierarchy, they were often used to defend the existing structure as well.

A new era of publications and studies on animal fables began in Europe in the 17th century C.E., inaugurated by the 12 books of La Fontaine (Fables de La Fontaine, 1668-1694), who regarded his own work as a translation of part of Phaedrus' fables; his fables primarily contained variants of the 'Aesopic' tradition. Until that time, fables were regarded as beneath poetry, but La Fontaine elevated the genre's artistic value to the highest level (Wright, 1881:xlv-xlvi). Many critics have maintained that he displayed the virtues of Aesop and Phaedrus combined. La Fontaine had himself claimed that animals possess not only souls but also the ability to think; he agreed that their thought was limited to immediate events and they could not process data a posteriori, and claimed that it differed from human thought not in type, but in depth. In his opinion, the ability to comprehend animals promoted self-knowledge, since both the good and evil of animals can be found in man (Noel, 1975:11).

An outburst of new fable collections and critics throughout Europe seems to have followed La Fontaine's publications, especially in France and later Germany, until the end of the 18th century; these were related to Aesop and were also conveyed through Phaedrus and other Latin fabulists. Many of these collections aimed to inspire moral values in (especially) young readers. Most fabulists also developed and published theories of animal fables, and many fables were published that aimed to follow a particular theory closely. This also led to the creation of fables concerning how a fable should be written.

In France Antoine Houdar de la Motte published in 1719 his Fables nouvelles, which is considered the first theoretical treatment of this genre and was allegedly recognized as "the father of fable theory". Henri Richer published his own Fables nouvelles 10 years later (1729). Both seemed to point out the element of didacticism in fables, mainly though indirect approach and simplification of abstract principles (Noel, 1975:45). They were soon followed by three others, who venerated La Fontaine and respected La Motte: Charles Batteux (Beaux Arts réduits à un meme principe, 1746, and Cours de belles-lettres, 1763), Jean François Marmontel (Élémens de literature, 1787) and the Abbé Jean-Louis Aubert, director of the Royal Gazette, who published his first fables in 1756, assuming a progressive stance, in regard to artistic originality (Noel, 1975:38-42, 75-82) and stressed the genre's continued viability. His fables were highly praised, but they were soon forgotten (Collins, 1882:145-146).

In Germany the fable appeared as the leader of the literary resurrection after the 1720's (though many editions of fables were continuously printed since the previous century), with many fabulists and many similar publications, like Der deutsche Aesop, a weekly devoted exclusively to fables. The poet Friedrich von Hagedorn became a landmark in German fable writing: in 1729 he published Versuch in poetischen Fabeln und Erzählungen he acknowledges La Fontaine's importance but also utilizes the works of Latin fabulists and contemporary English poets. One year later, Johahn Christoph Gottsched published Versuch einer critischen Dichtkunst für die Deutschen, where he tried to transcribe elements of French classicism into newly born German poetic tradition; he was criticized for that and soon a literary war erupted between Gottsched and his followers on the one side and their adversaries, represented mainly by the Swiss Johann Jakob Breitinger (Critische Dichtkunst, 1740), who characterized the fable as an instructive wonder, and Johann Jakob Bodmer ("Critical Introduction" to Ludwig Meyer von Kronau's Ein halbes Hundert neuer Fabeln, 1744) and their followers on the other. The Swiss faction seemed to favour English literary models. Gottsched was supported by Daniel Wilhelm Triller (Neue äsopische Fabeln, 1737) and Daniel Stoppe (Neue Fabeln oder moralische Gedichte, 1838). The former stressed the importance of the 'unbelievable' trait as the essence of fables. Another supporter of Bodmer, Christian Fürchtegott 
Gellert began publishing his own metric fables (in 1741 in the periodical Belustigungen des Verstandes und des Witzes) and essays (Abhandlungen von den Fabeln und deren Verfasser, 1744) pointing out imaginative invention as the essential quality of fables. In 1748, an unsigned article titled "On the Fable" appeared in the weekly moral Der Gesellige, calling the ideal fable a fairy tale with a moral (note 1).

Perhaps the more prominent figure in German fable scholarship of this era (and the Enlightenment in Germany, in general) was Gotthold Ephraim Lessing, who emerged as the representative and product of German Protestantism and the advocate of rule and order, depicting the fable as a mainly didactic tool, stripped of extraneous ornament or poetic play. He began publishing his own fables and related essays in 1747 (Fabeln und Erzählungen in Reimen); in 1759 (Babeln: Drei Bücher, which is considered the basis of his reform movement), though Lessing sought a return to the Aesopian prototype, eschewing La Fontaine and the poetic element of fable in general in favor of a more direct moral. As a result, later German critics referred to fables either as "Lessingsche" (short, simple, highly moral) or "Lafontainsche" (artistic). (Noel, 1975:96)

The pedagogue Johann Georg Sulzer [Versuch von der Erziehung und Unterweisung der Kinder (Experiment in the Education and Instruction of Children), 1748, Allgemeine Theorie der schönen Künste (General Theory of the Fine Arts), 1771-1774), and Vorübungen zur Erweckung der Aufmerksamkeit und des Nachdenkens (Preparatory Exercises to the Awakening of Alertness and reflection), 1768], suggested fables as the most favourable means of indirect teaching and integrated them in a graduated pattern of instruction from the lower grades through the gymnasium. He agreed with Lessing's characterization of the fable as a moral lesson and kept to the neoclassical principles of reason concerning its origins, but he also stressed the function of genius in its creation. (Noel, 1975:103-105, 123-124)

The fiercest 'counterattack' to Lessing's theories was led shortly after by Johann Jacob Bodmer with his parodic Lessinsche unäsopische Fabeln (1760); later (Preface to Historische Erzählungen, 1769), Bodmer rejected fables for stories based on historical events. The absence of poetic beauty in fables was also surely at odds with Romantics, such as Johann Georg Hamann and, especially, Johann Gottfried von Herder, who regarded the genre as something far more artistic and wondrous than a mere didactic tool; this contrast, concerning fables, was highly suggestive of "the difference between the neoclassical man of reason and the romantic follower of feeling and inspiration". Herder began publishing several articles on fables from 1767, where he defended La Fontaine against Lessing's rejection of the artistic beauty of the genre and depicted the fabulist as a 'natural' genius, opposed to conformed society. Johann Wolfgang von Goethe, criticizing a volume of fables and stories by H. Braun for the periodical Frankfurter gelehrte Anzeigen (1772), rejected the oppressive sway of rules and reason in the process of fable creation and claimed that fables were created in ancient times to express folk wisdom; later when true examples had lost their instructive value, people began to invent stories and set rules to fable creation, distorting them into mixtures of fable and story, aiming just to amuse, thus fables followed the decay of human society. (Noel, 1975:100-101, 125-135)

During the same period in England, animal fables were clearly regarded as children's literature, with pedagogic character, but unworthy of further discussion or analysis. However, at the end of this century there was a resurgence of interest in Aesop, an "Aesop craze" (Zafiropoulos, 2001:27), resulting in the publication of cheap popular booklets that only typically included the name of Aesop in their title.

Prior to the Glorious Revolution of 1688, fables like the Belly and the Members or the Frogs Desiring a King were circulated, aiming to defend arguments for or against monarchy. John Dryden with his Hind and the Panther (1687) even tried to avert the Revolution (Patterson, 1991:95); in 1700 he published Fables Ancient and Modern, signifying the turn of the Aesopic fable towards politics. The publication of Aesopic fables in the era of the Enlightenment, commenced by La Fontaine, was continued by Sir Roger L' Estrange (Fables of Aesop and Other Eminent Mythologists: With Morals and Reflections, 1692). L' Estrange's fables were established as the dominant form of Aesopic fables, being republished at least eight times until 1720. They exhibited political (anti-Whig) implications, especially after William's ascension to the throne in 1688, which is considered the starting point of the European Enlightenment (note 1). In 1722, Samuel Croxall (Fables of Aesop and Others... With an Application to each Fable) attempted to challenge L' Estrange's publications, as he considered them offensive because of their anti-Liberal stance, and because he regarded them as contrary to the genre's initial function. Croxall's work was also republished many times, and the juxtaposition of these two works appeared as a powerful tool of political argumentation between the Tories and the Liberals, which was continued by other similar efforts, such as John Gay's Fables (1727, 1738) (Patterson, 1991:139-149).

In 1761 Robert Dodsley published Selected Fables of Esop, and other Fabulists, prefaced by “An Essay on Fable", which is considered the "first and only attempt at a thorough study of the genre in England" (Noel, 1975:115). 
Moreover, his collection contained ancient and modern fables, but also many of his own (and some friends') writing. He insisted on maintaining the fables' allegory, in order to camouflage and stress their moral lesson. Dodsley was followed by others (cf. Noel, 1975:118-121) who, like him, regarded the fable as an excellent means of instruction.

In Spain fable interest began growing no later than 1781, when Félix María Samaniego published the first part of his Fábulas en verso castellano (the second part was published three years later), presenting his own reworking and theories of traditional fables. However, the prominent figure of Spanish fable scholarship was Don Tomás de Iriarte, who, in his Fábulas literarias (1782), composed his own fables in a neoclassical literary style, aiming rather towards esthetic than moral didacticism. Iriarte's fables were soon translated in German and in English. One year later (1783) Pablo Forner published (anonymously) El Asmo erudito, satirizing Iriarte and his works. It seems that two coalescing factions were formed behind these two authors, with Forner representing pre-Romanticism and Iriarte Neoclassicism. (Noel, 1975:140-144)

In Russia during the late 18th and early 19th centuries, social and political concerns gave rise to the agitational animal fable: for example, in 1803, the Decembrist activist Denis Davydov circulated his own version of the Aesopic fable "The Head and the [Lower] Limbs" (Note1). Similar fables, employing a direct or indirect approach, portrayed Aesop as a model fabulist, as he was delivered from slavery by narrating his fables (cf. Roemer, 1998:197; Author, 2002:225). In 1805 Ivan Krylov, the most distinguished Russian fabulist, began translating La Fontaine's fables, and later produced his own fables adapted to contemporary Russian society.

John Locke $(1693: 133,164)$ considered Aesop's fables the only book suitable for children and argued that fables should be one of their first readings, as they offer children thoughts and stimuli useful for their adult life, presented in a pleasant and comprehensible way. For this reason, as soon as they are able to read, children should come into contact with animal pictures, which would encourage them to approach reading and even to love it.

Interest in animal fables as an exemplary pedagogic tool was not limited to children. Already accepted as a distinct literary genre of pedagogic value or as a pedagogic means with the attractiveness of a literary work, fables were also addressed to adults for entertainment as well as moral education, and were considered suitable for the edification of the masses. Later, they acquired a special role in the social protest against traditional methods of moral education. At the end of the 18th century these fables were considered an expression (or residue) of the primordial natural unity of man with Nature, before it was disrupted by the conventionality of human culture. Romanticism prompted people to become one with Nature and to return, in a manner of speaking, to the Golden Era of spiritual unity with it. As a result, there was a turn towards animal fables, sometimes expressed as natural poetry, and towards popular tradition generally (cf. Noel, 1975:11-12; Author, 2005:224-225).

Apart from their supporters, animal fables also had opponents who did not accept them as a distinct literary genre and did not recognize their pedagogic value, perhaps preferring stories based on historical reality (Yannicopoulou, Liverpool 1993:144-148). Still others like Rousseau, who roundly criticized La Fontaine, rejected their appropriateness for children, arguing that children had not yet acquired sufficient contact with the world to comprehend fables' meaning, for fables were an effective means of determining and exploiting lessons emanating exclusively from experience, which children did not yet possess (Rousseau, 1762:261-276). According to him, fables were better suited for youths, able to comprehend and profit from their moral lesson (Note 1). Apart from that, Rousseau's views did not diminish the publication of fables in the 18th century.

Before examining the presence of Aesop in the Modern Greek Enlightenment, we should perhaps mention the case of the Greek Enlightenment of the 5th century B.C.E., which took place in classical Athens, with the Sophists as its main representatives. Their statements concerning isonomy, the contestation of hereditary superiority, and especially the value of education and individual worth do not strike us as irrelevant to the period under examination. Sometime later, comparable views were expressed, especially regarding the importance of personal development, by the Cynics, particularly Krates and Diogenes. The use of animals, not yet corrupted by civilization, to exemplify human beings, governed their approach. According to the eminent Aesopologist Rodríguez Adrados (2000:715; cf. Zafiropoulos, 2001:34-36), a large part of the corpus of Aesopic fables is comprised of Cynic doctrines, exploiting particular, already popular, fables in order to promote their political propaganda. Towards this goal, from the 3rd century B.C.E., they versified Phalereus' collection; these metrical fables were later restored to prose by the Stoics. Adrados based his theory on the existence of Aesopic fables of certain characteristic subjects, such as the disapproval of wealth, hypocrisy, arrogance, their criticism of established habits, and their respect for life. However, these views appear somewhat tenuous, since none of these thinkers (Sophists, Cynics, Stoics) left written documents expressing their views, which were in any event diffused through many philosophical movements and schools. 
A prose translation of 150 Aesopic fables into Modern Greek was published in 1543 in Venice by Andronikos Noukios and soon became very popular. Much later, in 1896, the previously unpublished metrical translation of 144 Aesopic fables by the monk Georgios Aitolos was published in Constantinople. These two publications were the first Modern Greek translations of Aesopic fables and enjoyed wide public acceptance. (Parasoglou, 1993)

Aesopic fables became very popular in the 19th century, as they were regarded as a highly effective pedagogic means, concerning the country's social conditions and cultural needs. Many writers attempted to adopt and adapt older fables (mainly those of La Fontaine). Aesop's fables constituted pleasant and instructive reading, addressed to every age and suitable for teaching, as they combined moral education with an appropriation of the ancient Greek heritage. We might argue that Aesop's fables satisfied the constant need of the Modern Greek Enlightenment for pleasant but beneficial readings and as such they were incorporated into the intellectual arsenal for the edification of the Greek nation. (Kaplanoglou, 2001:90-95; Malaphantes, 2001:92)

The importance and usefulness of Aesopic fables as children's reading was outlined in 1779 by Iosipos Moisiodax (1779:130-131), who regarded them (as did Locke, by whom he was greatly influenced), as the most appropriate reading material for this age group. He considered them particularly suitable for the learning of the Greek language because they were comprehensible and attractive, and because they inspired children's creativity. One may mention here the tendency of the Modern Greek Enlightenment to abandon meticulous moralizing and seek out more pleasant and attractive instructional texts.

In 1810, the great scholar Adamantios Korais published in Paris his Aesop's Fables, adding 36 new ones of his own (all except two with epimythia), signing them with the letters $\Lambda$. Z (note 1) The book had a clearly didactic goal; considering lying, in the special case of fables, as a form of art, Korais suggested that the ostensible truth of fables was fundamentally derived from the realistic representation of each animal's nature and morality. Moreover, he included 'principles' for composing animal fables, according to which animals should, for example, be presented in accordance with their natural traits, without excessive lies and obscenities. For this reason, he placed Aesopic fables first in the collection of texts to be established for Greek education and language learning.

Through this publication Korais wished, as he himself noted in the "Prolegomena" (Preface), to stimulate critical thought in young people, utilizing an integral part of Greek literature that had inspired many great individuals through the course of many centuries, and to rescue Greece from illiteracy. He referred at length to the genre's history and development and to other fabulists after Aesop. In another part of his book, reporting on previous collections and translations of Aesopic fables, he criticized similar attempts by monks, observing ironically that, according to their epimythia and conclusions, "all of us living on earth should don the monastic robe, if we want to be delivered" (Korais, 1810: $\mu \delta$ ).

Korais considered this publication important for four main reasons: a) these fables constitute part of Greek literature; b) he feels proud that they had been a source of inspiration for great minds, e.g. Phaedrus and La Fontaine; c) he considers them highly appropriate for language development, and d) he believes that through these fables critical thought can be cultivated in the young, which will rescue the nation from illiteracy. (Cf. Korais, 1810: $\sigma \alpha-v \gamma$; Malaphantes, 2001:76-90; Koukouredes, 1998:19-22)

Many of Korais' 'new' fables convey a message, mainly expressed in the epimythium, which was specifically addressed to the enslaved Greeks, urging them to fight, even at great cost, for their freedom. The third fable, entitled "Council of the Mice" (cf. Korais, 1810:498-500), is indicative. Here, the mice hold a council to decide how to get rid of the cats' oppressive tyranny. They decide to attack them all together, but when the moment comes, they all find an excuse to depart, and thus the cats continue unhindered to tyrannize them. As early as the freedman Phaedrus, Aesopic fables were often considered 'slave philosophy', and were appropriate for such utilization.

Moisiodax (1779:130-131) had already connected animal fables to the inclination people (especially children) feel towards animals, reminding us of the controversial 'natural connection' between children and animals. This connection, which would be intensified in the 19th century, led to the production of animal fables where the identification of children with the animals starring in them would became more evident, as these symbolic animals could be encountered in the 'real' world facing situations not so removed from those of everyday life. Here, one notices a distancing from the traditional function of fables, which can also lead to a complete inversion of a fable's initial message, as would later happen (Kaplanoglou, 2001:95-106) with "The Ant and the Grasshopper".

However, as is still the case, it was difficult to draw a distinguishing line between literature intended for children and literature intended for adults, as both groups had access to the various works of their time (even before the mass media appeared). In the case of animal fables, a fable would not differ much in form and content according to audience; what differentiated it was the way it was received and interpreted. An adult and a child could draw 
different conclusions from the same fable. Indeed, this characteristic adds much to fables' literary as well as pedagogic value, since a fable could effectively guide a person through many stages in life. (Author, 2005:55)

Therefore, it appears that the presence of animal fables became intense towards the end of the 17th century, and even more so in the first half of the 18th century. The fable's multiple uses start from literary pastime and reach pedagogic exploitation and often, indirect social and political expression or even protest, ever changing to meet society's cultural needs. As in the historical development of the genre, people of progressive spirit turned to fables to present the wider social strata with a pedagogic means that was comprehensible and pleasant as well as beneficial. Here too there was a "wolf" for the "sheep" to rise up against (Merakles, 1993:209-211): in the case of the European Enlightenment, this was usually some authoritarian regime or established order, while for the Modern Greek Enlightenment it was the illiteracy which tormented the sorely-tried Greek nation and from which many 'enlightened' persons tried mightily to liberate the Greeks, making Aesop and his fables the point of their 'intellectual spear'.

\section{References}

Aarne, A. and Thompson, S. (1961). The Types of the Folktale. A Classification and Bibliography. Second Revision (FF Communications 184). Helsinki.

Adrados and Francisco, R. (2000). History of the Graeco-Latin Fable. Vol. II - The Fable during the Roman Empire and in the Middle Ages. Translated by Leslie A. Ray. Leiden-Boston- Köln: Brill.

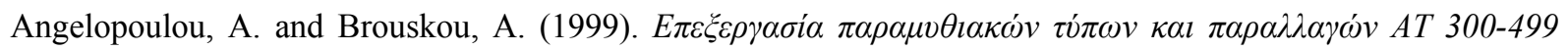
[Elaboration of Tale Types and Variations AT 700-749]. Athens: Modern Greek Research Center of National Research Center.

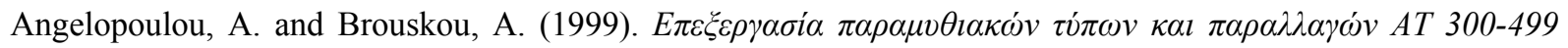
[Elaboration of Tale Types and Variations AT 300-499]. Vol. A' and B'. Athens: Modern Greek Research Center of National Research Center.

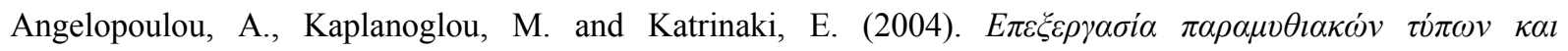
$\pi \alpha \rho \alpha \lambda \lambda \alpha \gamma \omega \dot{v}$ AT 500-559 [Elaboration of Tale Types and Variations AT 500-559]. Athens: Modern Greek Research Center of National Research Center.

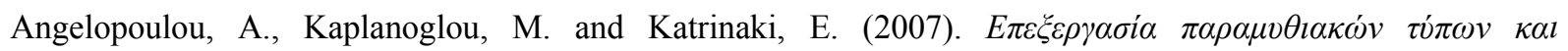
$\pi \alpha \rho \alpha \lambda \lambda \alpha \gamma \omega \dot{\omega}$ AT 560-699 [Elaboration of Tale Types and Variations AT 560-699]. Athens: Modern Greek Research Center of National Research Center.

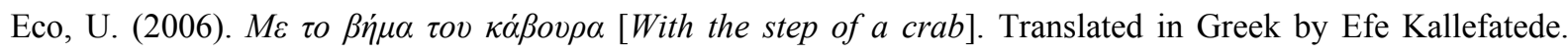
Athens: Ellinika Grammata.

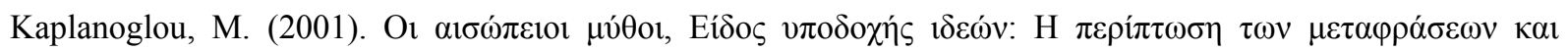

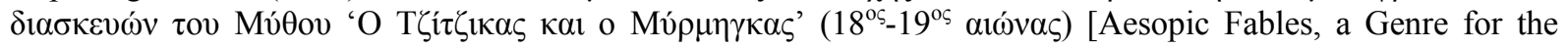
Receiving of Ideas: The Case of the Translations and Adaptations of 'The Ant and the Grasshopper' (18th-19th century)]. Nea Paideia, 97, 90-108.

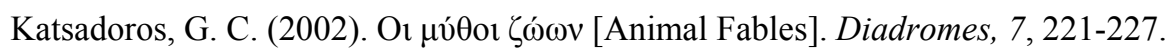

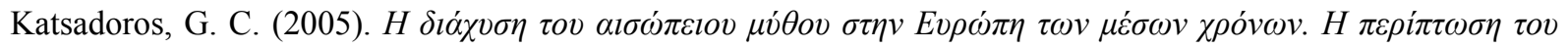
Odo of Cheriton [The Diffusion of Aesopic Fables in Middle Ages Europe. The Case of Odo of Cheriton]. Ph.D. Dissertation. Athens: University of Athens.

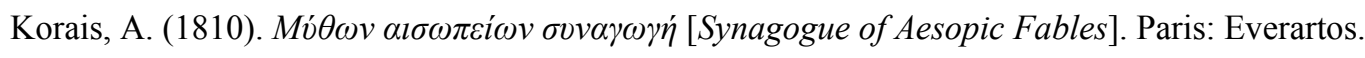

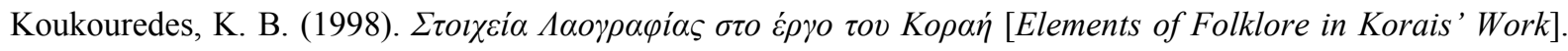
Athens: Alphaveto.

Locke, J. (1693). Some Thoughts Concerning Education. London: Churchill.

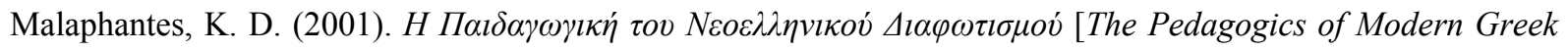
Enlightenment]. Athens: Poreia.

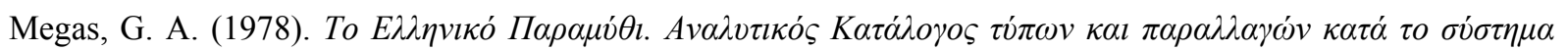

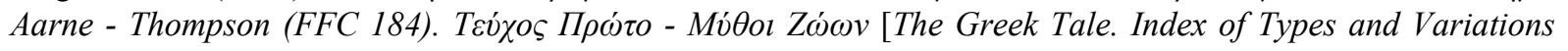
based on the Aarne - Thompson (FFC 184) Classification. Part I - Fables]. Athens: Research Center for Hellenic Folklore Publications, n. 14. 


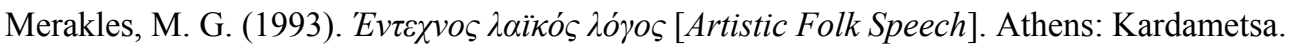

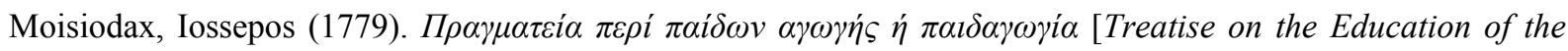
Youth]. Venice: Gkikos.

Noel, T. (1975). Theories of the Fable in the Eighteenth Century. Columbia University Press, U.S.A.

Papademetriou, Th. A. (1997). Aesop as an Archetypal Hero. Athens: Hellenic Society for Humanistic Studies International Centre for Humanistic Research.

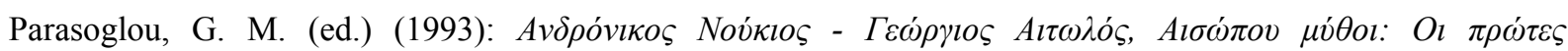

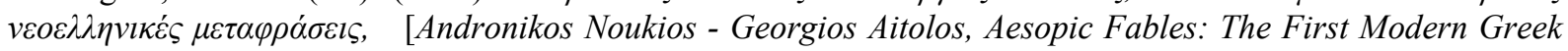
Translations]. Athens: Estia.

Patterson, A. (1991). Fables of Power. Durham \& London: Duke University Press.

Perry Ben Edwin (1952). Aesopica. Vol. I.U.S.A.: University of Illinois Press.

Roemer, D. M. (1998). Fable. Encyclopedia of Folklore and Literature, Brown, Mary Ellen and Rosenberg, Bruce A. (ed.).Santa Barbara, California: ABC-CLIO, 195-199.

Röhrich, L. (2008). And They Are Still Living Happily Ever After. Anthropology, Cultural History, and Interpretation of Fairy Tales. Translated in English by Paul Washbourne, Mieder Wolfgang and Wienker-Piepho, S. (ed.). Burlington, Vermont: Department of German and Russian, The University of Vermont.

Rousseau Jean-Jacques (1762). Émile ou de l' Éducation. Amsterdam.

Stamoulakes, I. P. and Makregianne, E. D. (translation). (1999). The Perriana version of the Aesop Romance (in Greek). Athens: Hellenic Society for Humanistic Studies - International Centre for Humanistic Research, 1999.

Uther, H. J. (2004). The Types of International Folktales. A Classification and Bibliography (FF Communications 284-6). Helsinki.

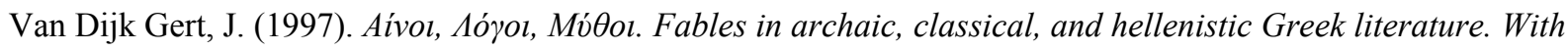
a Study of the Theory and Terminology of the Genre. Leiden-Boston- Köln: Brill.

Yannicopoulou, A. (1993). Fables and children - Form \& function. Liverpool: Manutius Press.

Zafiropoulos, C. A. (2001). Ethics in Aesop's fables: the “Augustana” collection. Leiden-Boston- Köln: Brill.

Note

Note 1. The adjective 'Aesopic' constitutes a philological invention that aims to show the various terms that denoted this literary genre. Aesop was considered the patriarch of fables without actually being recognized as the first who composed them. Rather, his person was selected because of his contribution to the genre (Zafiropoulos, 2001: 10-12). 